\title{
Multiple Cross Displacement Amplification-a more applicable technique in detecting Pseudomonas Aeruginosa of Ventilator-associated Pneumonia( VAP)
}

Juxiang Wang

xiamen Cardiovascular Hospital, Xiamen University

Huimin Chen

the third hospital of xiamen

Xiaomin Lin

Xiamen Branch, Zhongshan Hospital, Fudan Unversity

Chengyi Ji

the third hospital of Xiamen

Bin Chen ( $\sim$ drchenbin@126.com)

Xiamen Port Clinic of Xiamen Customs https://orcid.org/0000-0002-3152-4021

\section{Research}

Keywords: Pseudomonas aeruginosa, multiple cross displacement amplification, ventilated-associated pneumonia, bronchoalveolar lavage fluid, Limit of Detection

Posted Date: February 7th, 2020

DOI: https://doi.org/10.21203/rs.2.22930/v1

License: (c) (i) This work is licensed under a Creative Commons Attribution 4.0 International License.

Read Full License

Version of Record: A version of this preprint was published at Critical Care on June 8th, 2020. See the published version at https://doi.org/10.1186/s13054-020-03003-4. 


\section{Abstract}

Background Early and rapid identification of $\mathrm{P}$ seudomonas aeruginosa (PA) in patients with suspected ventilator-associated pneumonia (VAP)provides theoretical clinical advantages in therapeutic optimization strategies.

Methods The PA-MCDA assay was conducted at an isothermal temperature during the amplification stage, and products were visually detected by color changes. The entire process was completed within 1 h. A total of 77 strains, including PA species and various other species of non- PA were used to evaluate PA -MCDA assays. Bronchoalveolar lavage fluid (BALF) of suspected VAP patients were examined by the MCDA assay.

Results. The MCDA assay exhibited a 100 percent analytical specificity in detecting PA from all 77 strains, and the limits of detection limit were as low as $100 \mathrm{fg}$ DNA per reaction. A temperature of $65^{\circ} \mathrm{C}$ was recommended as standard during the amplification stage. Of all 26 BALF specimens, the approach could recognize 8 PA from the BALF specimens without the need for bacterial culture, from which, 7 were positive and 1 was negative.

Conclusions. The instrument-free platform of the MCDA assay makes it a simple, rapid and applicable procedure for "on-site" diagnosis and point-of-care testing for the presence of PA without the need for specific bacterial culture.

\section{Background}

Ventilator-associated pneumonia (VAP) develops in intensive care unit (ICU) patients that have been mechanically ventilated for at least $48 \mathrm{~h}[1]$. The infection rate was related to disease severity and the degree of organ failure[2]. Further, the EU-VAP study[3]identified that the overall incidence of VAP was 18.3 episodes per 1000 ventilator-days. Moreover, Pseudomonas aeruginosa (PA) and Staphylococcus aureus (SA) were the most frequently isolated pathogens in patients with VAP. In a multicenter study[4], P. aeruginosa, A. baumannii, and Klebsiella pneumonia were found the most frequent bacteria $(97 / 212$, $45.8 \%$ ) in VAP patients. In addition, VAP induced a more prolonged need for mechanical ventilation, number of ICU stays and hospitalization, far worse outcomes, and increased associated healthcare costs $[5,6]$.

Rapid completion of antibiotic administration might decrease the incidence of subsequent organ dysfunction and could be associated with a lower risk-adjusted in-hospital mortality rate [7]. The conventional detection of PA in the clinical setting was generally achieved by growing the target pathogen on either nail dixic acid-cetrimide agar or cetrimide agar cultures. Although the culture-based technique is reliable, the time needed for conducting it is at least for a period of $48 \mathrm{~h}$ [8]. Furthermore, published guidelines recommended an initial empiric combinatorial coverage with antibiotics targeted to Gram-negative and Gram-positive bacteria (MRSA) in the setting of high-risk VAP patients prior to obtaining culture results[1]. Inappropriate initial anti-microbial therapy and antibiotic exposure attributed 
to antibiotic-resistance[9, 10]was associated with increased in-hospital mortality rates [11]. Rapid and accurate identification of the suspected pathogens, i.e., PA, is thus warranted to avoid a need for empiric broad-spectrum and combinatorial antibiotic therapy, because it provides the potential to maximize administration of appropriate and specific antibiotic therapy while minimizing the potential for unnecessary antibiotic exposure.

More recently, multiple cross displacement amplification (MCDA, Chinese IP Office Patent Application CN201510280765.X), auto-cycling, and strand displacement DNA synthesis was devised and validated as a possible replacement for PCR-based assays and applicability in the detection of specific nucleic-acid sequences$[12,13]$. The assay employed an isothermal temperature during amplification, and the products were visually detected by color changes. The entire process is completed in $2 \mathrm{~h}$ and benefits from being an instrument-free, simple and practical procedure for 'on-site' diagnosis and point-of-care testing. The current study is the first to report application of the novel MCDA assay to rapidly detect the target pathogen, PA.

\section{Methods}

PA-MCDA assay primer design

Based on the mechanism of MCDA, a set of MCDA primers used for PA detection was designed that targeted the oprL gene, which encodes L-lipoprotein. The details of MCDA primers used in the report are shown in Fig. 1 and Table 1. The primers were commercially synthesized and purified by Tsingke (Beijing, China). 
Table 1

Primers used for multiple cross displacement amplification in this study.

\begin{tabular}{|lll|}
\hline Primers & Sequences $\left(\mathbf{5}^{\prime} \mathbf{3}^{\prime}{ }^{\prime}\right)$ & Length \\
\hline CP1 & GCCGAATTTCAGCATTTCCATCATG-CCTGAACTGACGGTCGCC & $43 \mathrm{mer}$ \\
CP2 & CGATGCTTCCGGTGAAGGTGC-AACGGCACCGCTGTTG & $37 \mathrm{mer}$ \\
\hline F1 & GCCTTCCTGGTCCCCTTA & $18 \mathrm{nt}$ \\
\hline F2 & CGGCTTCGTCGCTCAG & $16 \mathrm{nt}$ \\
C1 & GCCGAATTTCAGCATTTCCATCATG & $25 \mathrm{nt}$ \\
C2 & CGATGCTTCCGGTGAAGGTGC & $21 \mathrm{nt}$ \\
D1 & ACTCCTAATGAACCCCAGT & $19 \mathrm{nt}$ \\
D2 & ACCCGAACGCAGGCTATG & $18 \mathrm{nt}$ \\
R1 & CAGAGCCAGCGCAGCA & $16 \mathrm{nt}$ \\
R2 & GGCTGTGGCTGTGGGT & $16 \mathrm{nt}$ \\
\hline P1 & CCTGAACTGACGGTCGCC & $18 \mathrm{nt}$ \\
\hline P2 & AACGGCACCGCTGTTG & $16 \mathrm{nt}$ \\
\hline
\end{tabular}

\section{PA-MCDA reactions}

MCDA reactions were performed in a one-step reaction in a $25 \mu \mathrm{l}$ mixture containing $12.5 \mu \mathrm{l} 2 \times$ the supplied buffer (BeiJing- Hai Tai Zheng Yuan Technology Co., Ltd.), $0.1 \mu$ l each of the displacement primers F1 and F2, $0.2 \mu$ l each of the amplification primers C1, C2, R1, R2, D1 and D2, $0.4 \mu$ l each of the cross primers $\mathrm{CP} 1$ and $\mathrm{CP} 2,1 \mu \mathrm{l}(8 \mathrm{U})$ of Bst 2.0 DNA polymerase, $1 \mu \mathrm{l}$ of the DNA template and $0.8 \mu \mathrm{l}$ of the colorimetric indicator. Moreover, negative control mixtures contained $10 \mathrm{ng}$ of the Staphylococcus aureus (SA) and Klebsiella pneumoniae (KP) genomic templates, and blank control mixtures contained $1 \mu \mathrm{l}$ of double distilled water (DW).

To evaluate the feasibility of the MCDA primer set that was designed to detect PA, we initially conducted the MCDA reactions at $63^{\circ} \mathrm{C}$ for $45 \mathrm{~min}$ and terminated the MCDA reaction by heating at $85^{\circ} \mathrm{C}$ for 5 min. Then, the optimal amplification temperature of the MCDA primer set was examined at fixed temperatures from $59^{\circ} \mathrm{C}-68^{\circ} \mathrm{C}$ at steps of $1^{\circ} \mathrm{C}$ intervals. In particular, MCDA products were detected using a colorimetric indicator and agarose gel electrophoresis.

Bacterial strains and genomic template preparation

A total of 77 bacterial strains (see Table 2) from the clinical microorganism laboratory of the Third Hospital of Xiamen were selected, from which, 17 PA and 60 non-PA strains were identified by MALDI-TOF 
(microflex LT/SH, Bruker Corporation, Karlsruhe, Germany) were stored in a 15\% (w/v) glycerol broth at $-70^{\circ} \mathrm{C}$. After refreshing the culture three times on a nutrient agar plate at $37^{\circ} \mathrm{C}$, the genomic templates were then extracted from all cultured strains using DNA extraction kits (Qiagen Co.Ltd. Beijing, China), and subsequently tested with an ultraviolet spectrophotometer and stored under $-20^{\circ} \mathrm{C}$ before use.

\section{Table 2. List of bacterial strains}

A total of 77 bacterial strains, which included 17 PA and 60

non-PA strains were identified by MALDI-TOF (microflex

LT/SH, Bruker corporation, Karlsruhe, Germany) by the

clinical microorganism laboratory of the Third Hospital of

Xiamen.

\begin{tabular}{|l|l|l|l|}
\hline bacteria & strains & bacteria & Strains \\
\hline $\begin{array}{l}\text { Pseudomonas. } \\
\text { aeruginosa }\end{array}$ & 17 & $\begin{array}{l}\text { Streplococcus } \\
\text { agalactiae }\end{array}$ & 5 \\
\hline Escherichia coli & 5 & $\begin{array}{l}\text { Enterococcus } \\
\text { faecalis }\end{array}$ & 5 \\
\hline $\begin{array}{l}\text { Staphylococcus. } \\
\text { aureus }\end{array}$ & 5 & $\begin{array}{l}\text { Salmonella } \\
\text { typhimurium }\end{array}$ & 5 \\
\hline $\begin{array}{l}\text { Acinetobacter } \\
\text { baumannii }\end{array}$ & 5 & $\begin{array}{l}\text { Klebsiella. } \\
\text { pneumoniae }\end{array}$ & 5 \\
\hline $\begin{array}{l}\text { Staphylococcus } \\
\text { epidermidis }\end{array}$ & 5 & $\begin{array}{l}\text { Enterobacter } \\
\text { cloacae }\end{array}$ & 5 \\
\hline $\begin{array}{l}\text { Staphylococcus } \\
\text { capitis }\end{array}$ & 5 & $\begin{array}{l}\text { Stenotrophomonas } \\
\text { maltophilia }\end{array}$ & 5 \\
\hline $\begin{array}{l}\text { Streptococcus } \\
\text { pyogenes }\end{array}$ & 5 & 5 & \\
\hline
\end{tabular}

Table 2

List of bacterial strains

Specificity of the PA -MCDA assay

To evaluate the analytical specificity of the PA-MCDA assay, MCDA reactions were conducted under conditions that were described above with the 77 PA and non-PA pure genomic templates that were derived from all pure bacterial strains.

Sensitivity of the PA-MCDA assay 
The genomic templates of PA were serially diluted (10 ng, $1 \mathrm{ng}, 100 \mathrm{pg}, 10 \mathrm{pg}, 1 \mathrm{pg}, 100 \mathrm{fg}, 10 \mathrm{fg}$ and $1 \mathrm{fg}$ per microliter) with the intent of verifying the limit of detection (LOD), and $1 \mu$ of each serial dilution was then added to the MCDA reaction mixtures. The LoD of the MCDA assay was confirmed by the genomic DNA concentration of the template. MCDA results were detected using a colorimetric indicator (BeiJingHai Tai Zheng Yuan Technology Co., Ltd.) and 2.5\% agarose gel electrophoresis.

Verification of the PA-MCDA assay

A total of 26 BALF were abstracted from patients that were aged $\geq 18$ years and who presented with suspected VAP. The patients satisfied two or more of the following criteria: fever $>38.5^{\circ} \mathrm{C}$, leukocytosis $>$ $10^{9} / \mathrm{L}$ or leukopenia $<4 \times 10^{8} / \mathrm{L}$, purulent tracheobronchial secretions, and a new or persistent infiltrate on chest radiography. The BALF were abstracted in one bottle, following which, one half $(5 \mathrm{ml})$ was stored at $-70^{\circ} \mathrm{C}$ and the other $5 \mathrm{ml}$ was sent for standard culture in the clinical microorganism laboratory of the Third Hospital of Xiamen. The DNA extraction from BALF method was the same as described before. In this procedure, $1 \mathrm{ul}$ of the extracted DNA template of the BALF specimen was added to the PA-MCDA assay and the reactions were conducted at an optimal amplification temperature for $45 \mathrm{~min}$. The products were detected by a color change and compared to the results of a standard clinical culture, which was blinded to the research investigators.

This study was approved by the local ethics committee of the Third Hospital of Xiamen, and performed according to the ethical standards of the latest revision of the Declaration of Helsinki. Written and informed consent was obtained from family members or the appropriate responsible parties.

\section{Results}

\section{Successful establishment of the PA-MCDA assay}

To verify the feasibility of PA-MCDA primers, the MCDA reactions were initially carried out in the presence or absence of genomic DNA templates within $45 \mathrm{~min}$ at a constant temperature of $63^{\circ} \mathrm{C}[12]$. A color shift of positive amplification in PA-MCDA tubes was directly observed to change from one of colorless to one of green, while the negative control tube remained colorless by the naked eye (Fig. 2A). The positive MCDA products were seen as ladder-liker patterned bands on ethidium bromide-stained $2.5 \%$ agarose gels that were resolved by electrophoresis; however, these were not seen in the S. aureus, K. pneumonia or blank control (Fig. 2B). Hence, the designed MCDA primer was a good candidate to establish the MCDA methodology for detecting PA.

\section{Optimizing the temperature for the PA-MCDA assay}

To confirm the optimal reaction temperature for the PA-MCDA assay, the PA strain was used as a positive control at a concentration of $1 \mathrm{ng}$ per tube and the MCDA amplifications were monitored by a real-time turbidity technique. Performing the PA-MCDA assay at temperatures that ranged from $59^{\circ} \mathrm{C}$ to $67^{\circ} \mathrm{C}$ at $1^{\circ} \mathrm{C}$ 
increments, verified that $65^{\circ} \mathrm{C}$ was an optimal temperature for amplification - with a faster amplification procedure obtained from assay temperatures of $65^{\circ} \mathrm{C}$ (Fig. 3.).

\section{Specificity and sensitivity for PA detection by MCDA assays}

When genomic templates were used in MCDA assays, only the genomic DNAs that were isolated from the PA strains (tubes 1 to 17) generated positive results. Genomic templates from all non-PA strains (1tubes 8 to 34) did not provide production of detectable amplification products (Fig. 4). The color change was observed in positive MCDA tubes (tubes 1 to 17), and a ladder-like pattern was seen on an ethidium bromide-stained $2.5 \%$ agarose gel via electrophoresis resolution. These were not seen in negative tubes (Fig. 4).

Serial dilution of the PA genomic DNA (10 ng, $1 \mathrm{ng}, 100 \mathrm{pg}, 10 \mathrm{pg}, 1 \mathrm{pg}, 100 \mathrm{fg}, 10 \mathrm{fg}$ and $1 \mathrm{fg}$ per microliter) were used in MCDA assays. When the dilution exceeded $100 \mathrm{fg} / \mathrm{uL}$, the green color by MG, the ladder pattern by agarose gel electrophoresis, and the positive reactions on real-time turbidity products were all directly observed (Figs. 5A and 5B). It indicated that the LoD, and the sensitivity of the PA-MCDA assay was $100 \mathrm{fg}$ genomic templates per reaction.

\section{Application of PA-MCDA to clinical samples}

The MCDA assay was used to examine 26 BALF from patients who were suspected of presenting with VAP. After extracting DNA from these BALF specimens and adding1ul of the DNA template to the PAMCDA assay, the reactions were carried out at $65^{\circ} \mathrm{C}$ for $45 \mathrm{~min}$ and the results were compared to those of the standard culture. The PA-MCDA assay detected 8 PA among which, 7 were found to be positive, and 1 was found to be negative by standard culture. The results of the other 18 BALF specimens were negative, and the standard culture was non-PA or indeed not positive for any other strain of bacteria. The PA-MCDA assay could identify one PA, while the standard culture could not identify PA.

\section{Discussion}

The PA-MCDA reaction was performed with a set of 10 oligo nucleo tide primers, which specifically recognized 10 distinct sites on the target sequence, wherein the optimal temperature for amplification was $65^{\circ} \mathrm{C}$. In particular, a colorimetric indicator (malachite green, MG) had been applied and the color changed from colorless to a light green color when the reaction was positive. The specificity of the PAMCDA assay was 100 percent, and the sensitivity achieved a level as low as $100 \mathrm{fg}$ of the template. The entire procedure, including that of specimen processing (15 $\mathrm{min})$, the isothermal reaction, and result reporting (45 $\mathrm{min})$, could be completed in approximately $1 \mathrm{~h}$. The positive results of the PA-MCDA assay corresponded to the standard culture in clinical samples; i.e., in BALF specimens. However, it identified one PA, while the standard culture could not detect it.

A rapid, simple and accurate detection method of pathogenic microorganisms is necessary for the timely administration of appropriate therapy and arriving at a time to discontinue unnecessary antibiotic(s). 
Delayed receipt of an appropriate antibiotic(s) was independently associated with poorer clinical and economic outcomes in patients with serious Gram-negative bacterial infections, regardless of any resistance status[8].Molecular diagnostic assays, such as PCR-based methods (e.g., conventional PCR, real-time PCR [14], and PCR-Electro Spray Ionization MS (PCR/ESI-MS)[15], permit more rapid detection of targeted bacterium by nucleic acid amplification, and have been established and applied in the clinic. However, these PCR-based techniques have some shortcomings, which include the following: (i) the instrument used is extremely expensive; (ii) the diagnostic specificity is highly affected by the amplification conditions and the primer design; (iii) use of these techniques indicate that PCR results require gel electrophoretic analysis or real-time analytical apparatus. Matrix-assisted laser desorption/ionization time of flight mass spectrometry (MALDI-TOF)[16] consistently decreased the time for successful identification of the pathogenic organism, shorten the period of time for administering an effective and optimal antibiotic and thus arrive at improved patient outcomes. However, it also needs a bacterial culture and expensive instruments.

The PA-MCDA assay represents a rapid, sensitive and nearly instrument-free method of PA detection. Only a water bath or heat block was needed during the reaction stage and the results could be read by the naked eye. Due to MCDA being able to provide results within only one hour, the clinician can save time to providing targeted therapy for patients, especially in the context of severe sepsis or septic shock patients. The PA-MCDA assay also detected a positive PA hit among 26 BALF specimens, while the result of the standard culture was negative. This trauma patient, who was 65 years old, had a maximum temperature of $39.5^{\circ} \mathrm{C}$, leukocytosis of $16.03^{\star} 10^{9} / \mathrm{L}$, purulent tracheobronchial secretions, and a persistent infiltrate on chest radiography during ICU therapy. His clinical and X-ray symptoms recovered, and the trachea was subsequently extubated following use of Meropenem and ventilator bundles[1]. The interpretation might suggest the MCDA approach having a higher sensitivity than standard culture[13,17], or that the PA had become non-viable before or even between the standard culture periods since the growth conditions had changed. In addition, the physician could use the PA-MCDA assay as a diagnostic aid, which could be associated with other laboratory and clinical information to establish a diagnosis of VAP and provide an appropriate antibiotic in order to reduce antibiotic exposure in suspected VAP patients, and to improve the accuracy of the results.

This study also has limitations. The first is that it can identify the target pathogen, PA, but it cannot differentiate the infection from a colonization. In addition, whether or not the assay could detect the target pathogen in other specimens such as from the blood, urine or serous effusion needs further study. The following step is to expand detection of the samples and to use the MCDA assay to identify resistance-associated genes (e.g., the $\mathrm{nfxB}$ gene and the blaPER-1 gene) $[15,16,18,19]$ associated with $\mathrm{PA}$, with the intention of selecting the appropriate antibiotic owing to its ability to accumulate different resistance mechanisms[20]. Consequently, the MCDA assay can only detect one kind of bacterium, while the presence of other pathogens are quite numerous. We plan to assign some microorganism-specific MCDA assays that are aligned to common pathogens found in the ICU, which would include S. aureus, A. baumannii, E. coli, fungal species, and others in one template. 


\section{Conclusions}

The PA-MCDA assay for rapid detection of PA, which was based on the oprL gene was successfully developed. This approach enabled its reaction products to be identified by the naked eye, and the assay established a high degree of both specificity and sensitivity for target template analysis. The PA-MCDA assay does not have the benefit of a rapid, reliable and nearly instrument-free procedure, but it can differentiate PA from pure strains of bacteria and clinical specimens without the need for time-consuming bacterial culture.

\section{Declarations}

\section{Acknowledgements}

This study was supported by the Third Hospital of Xiamen Affiliated of Fujian University of Traditional Chinese Medicine. We would also like to express our gratitude to the clinicians and healthcare professionals who helped us in this study.

\section{Funding}

This study was supported by a grant from the Medical Innovation Project of Fujian Province funded by the Xiamen Municipal Health Commission [grant number 2015-CXB-48]

\section{Availability of data and materials}

The dataset analysed during the current study is available from the corresponding author on reasonable request.

Authors' contributions

The corresponding author (BC) was in charge of study design. The first author (JXW) was responsible for manuscript writing and cooperated with the rest three authors (HMC, XML and CYJ) in clinical research work. JXW was in charge of data collection and experiment, $\mathrm{BC}$ was responsible for data analysis. $\mathrm{HMC}, \mathrm{XML}$ and $\mathrm{CYJ}$ were responsible for sample collection, experiment technical and material support during the

study. All authors have read and approved the publication of this manuscript. 
Ethics approval and consent to participate

All procedures in the study were performed in accordance with the ethical standards of the institutional research committee and with the 1964 Declaration of Helsinki and its later amendments or comparable ethical standards. Written and informed consent was obtained from family members or the appropriate responsible parties.

Consent for publication

Not applicable

\section{Competing interests}

All authors declared that they have no competing interests.

\section{References}

1. Torres A, Niederman MS, Chastre J, Ewig S, Fernandez-Vandellos P, Hanberger H, Kollef M, Li Bassi G, Luna CM, Martin-Loeches I et al: International ERS/ESICM/ESCMID/ALAT guidelines for the management of hospital-acquired pneumonia and ventilator-associated pneumonia. Guidelines for the management of hospital-acquired pneumonia (HAP)/ventilator-associated pneumonia (VAP) of the European Respiratory Society (ERS), European Society of Intensive Care Medicine (ESICM), European Society of Clinical Microbiology and Infectious Diseases (ESCMID) and Asociación Latinoamericana del Tórax (ALAT) 2017, 50(3):1700582.

2. Vincent JL, Rello J, Marshall J, Silva E, Anzueto A, Martin CD, Moreno R, Lipman J, Gomersall C, Sakr $Y$ et al: International study of the prevalence and outcomes of infection in intensive care units. Jama 2009, 302(21):2323-2329.

3. Koulenti D, Tsigou E, Rello J: Nosocomial pneumonia in 27 ICUs in Europe: perspectives from the EUVAP/CAP study. European journal of clinical microbiology \& infectious diseases : official publication of the European Society of Clinical Microbiology 2017, 36(11):1999-2006.

4. Cisneros JM, Rosso-Fernández CM, Roca-Oporto $C$, De Pascale G, Jiménez-Jorge S, FernándezHinojosa E, Matthaiou DK, Ramírez P, Díaz-Miguel RO, Estella A et al: Colistin versus meropenem in the empirical treatment of ventilator-associated pneumonia (Magic Bullet study): an investigatordriven, open-label, randomized, noninferiority controlled trial. Critical Care 2019, 23(1):383.

5. Safdar N, Dezfulian C, Collard HR, Saint S: Clinical and economic consequences of ventilatorassociated pneumonia: a systematic review. Crit Care Med 2005, 33(10):2184-2193. 
6. Zimlichman E, Henderson D, Tamir O, Franz C, Song P, Yamin CK, Keohane C, Denham CR, Bates DW: Health Care-Associated Infections: A Meta-analysis of Costs and Financial Impact on the US Health Care SystemMeta-analysis of Health Care-Associated InfectionsMeta-analysis of Health CareAssociated Infections. JAMA Internal Medicine 2013, 173(22):2039-2046.

7. Rhodes A, Evans LE, Alhazzani W, Levy MM, Antonelli M, Ferrer R, Kumar A, Sevransky JE, Sprung CL, Nunnally ME et al: Surviving Sepsis Campaign: International Guidelines for Management of Sepsis and Septic Shock: 2016. Intensive care medicine 2017, 43(3):304-377.

8. Bonine NG, Berger A, Altincatal A, Wang R, Bhagnani T, Gillard P, Lodise T: Impact of Delayed Appropriate Antibiotic Therapy on Patient Outcomes by Antibiotic Resistance Status From Serious Gram-negative Bacterial Infections. The American Journal of the Medical Sciences 2019, 357(2):103110.

9. Ong DS, Jongerden IP, Buiting AG, Leverstein-van Hall MA, Speelberg B, Kesecioglu J, Bonten MJ: Antibiotic exposure and resistance development in Pseudomonas aeruginosa and Enterobacter species in intensive care units. Crit Care Med 2011, 39(11):2458-2463.

10. Kollef KE, Schramm GE, Wills AR, Reichley RM, Micek ST, Kollef MH: Predictors of 30-Day Mortality and Hospital Costs in Patients With Ventilator-Associated Pneumonia Attributed to Potentially Antibiotic-Resistant Gram-Negative Bacteria. CHEST 2008, 134(2):281-287.

11. Micek ST, Wunderink RG, Kollef MH, Chen C, Rello J, Chastre J, Antonelli M, Welte T, Clair B, Ostermann $\mathrm{H}$ et al: An international multicenter retrospective study of Pseudomonas aeruginosa nosocomial pneumonia: impact of multidrug resistance. Critical care (London, England) 2015, 19(1):219-227.

12. Wang Y, Wang Y, Luo L, Liu D, Luo X, Xu Y, Hu S, Niu L, Xu J, Ye C: Rapid and Sensitive Detection of Shigella spp. and Salmonella spp. by Multiple Endonuclease Restriction Real-Time Loop-Mediated Isothermal Amplification Technique. Front Microbiol 2015, 6:1400-1400.

13. Wang Y, Wang Y, Ma A-J, Li D-X, Luo L-J, Liu D-X, Jin D, Liu K, Ye C-Y: Rapid and Sensitive Isothermal Detection of Nucleic-acid Sequence by Multiple Cross Displacement Amplification. Sci Rep 2015, 5:11902-11902.

14. Frye AM, Baker CA, Rustvold DL, Heath KA, Hunt J, Leggett JE, Oethinger M: Clinical impact of a realtime PCR assay for rapid identification of staphylococcal bacteremia. J Clin Microbio/ 2012, 50(1):127-133.

15. Bogaerts P, Hamels S, de Mendonca R, Huang T-D, Roisin S, Remacle J, Markine-Goriaynoff N, de Longueville F, Plüster W, Denis $O$ et al: Analytical validation of a novel high multiplexing real-time PCR array for the identification of key pathogens causative of bacterial ventilator-associated pneumonia and their associated resistance genes. Journal of Antimicrobial Chemotherapy 2012, 68(2):340-347.

16. Huang AM, Newton D, Kunapuli A, Gandhi TN, Washer LL, Isip J, Collins CD, Nagel JL: Impact of Rapid Organism Identification via Matrix-Assisted Laser Desorption/lonization Time-of-Flight 
Combined With Antimicrobial Stewardship Team Intervention in Adult Patients With Bacteremia and Candidemia. Clinical Infectious Diseases 2013, 57(9):1237-1245.

17. Kumar A, Ellis P, Arabi Y, Roberts D, Light B, Parrillo JE, Dodek P, Wood G, Kumar A, Simon D et al: Initiation of Inappropriate Antimicrobial Therapy Results in a Fivefold Reduction of Survival in Human Septic Shock. CHEST 2009, 136(5):1237-1248.

18. Jenny M, Kingsbury J: Properties and Prevention: A Review of Pseudomonas aeruginosa. J Biol Med Res 2018, 2 (3):8.

19. Evans SR, Tran TTT, Hujer AM, Hill CB, Hujer KM, Mediavilla JR, Manca C, Domitrovic TN, Perez F, Farmer M: Rapid Molecular Diagnostics to Inform Empiric Use of Ceftazidime/Avibactam and Ceftolozane/Tazobactam Against Pseudomonas aeruginosa: PRIMERS IV. Clinical Infectious Diseases 2018.

20. Giani T, Arena F, Pollini S, Di Pilato V, D'Andrea MM, Henrici De Angelis L, Bassetti M, Rossolini GM, Group PaW: Italian nationwide survey on Pseudomonas aeruginosa from invasive infections: activity of ceftolozane/tazobactam and comparators, and molecular epidemiology of carbapenemase producers. Journal of Antimicrobial Chemotherapy 2017, 73(3):664-671.

\section{Figures}




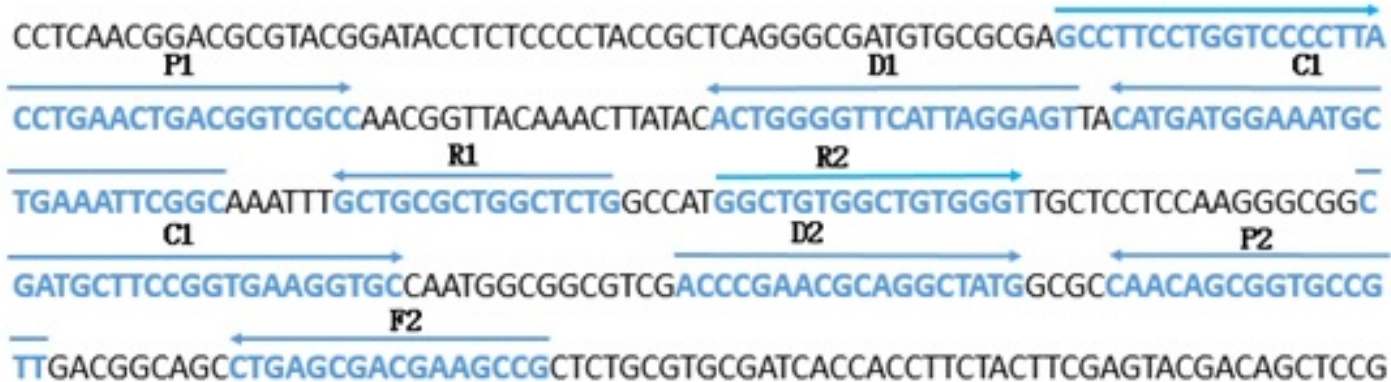

TTGACGGCAGCCTGAGCGACGAAGCCGCTCTGCGTGCGATCACCACCTTCTACTTCGAGTACGACAGCTCCG

\section{Figure 1}

Schematic depiction of the primer sequences and positions for MCDA. The location and nucleotide sequence of the PA oprL gene that assisted in designing MCDA primers. The primer site sequences are underlined. Right and left arrows indicate sense and complementary sequences that were used in the assay. 


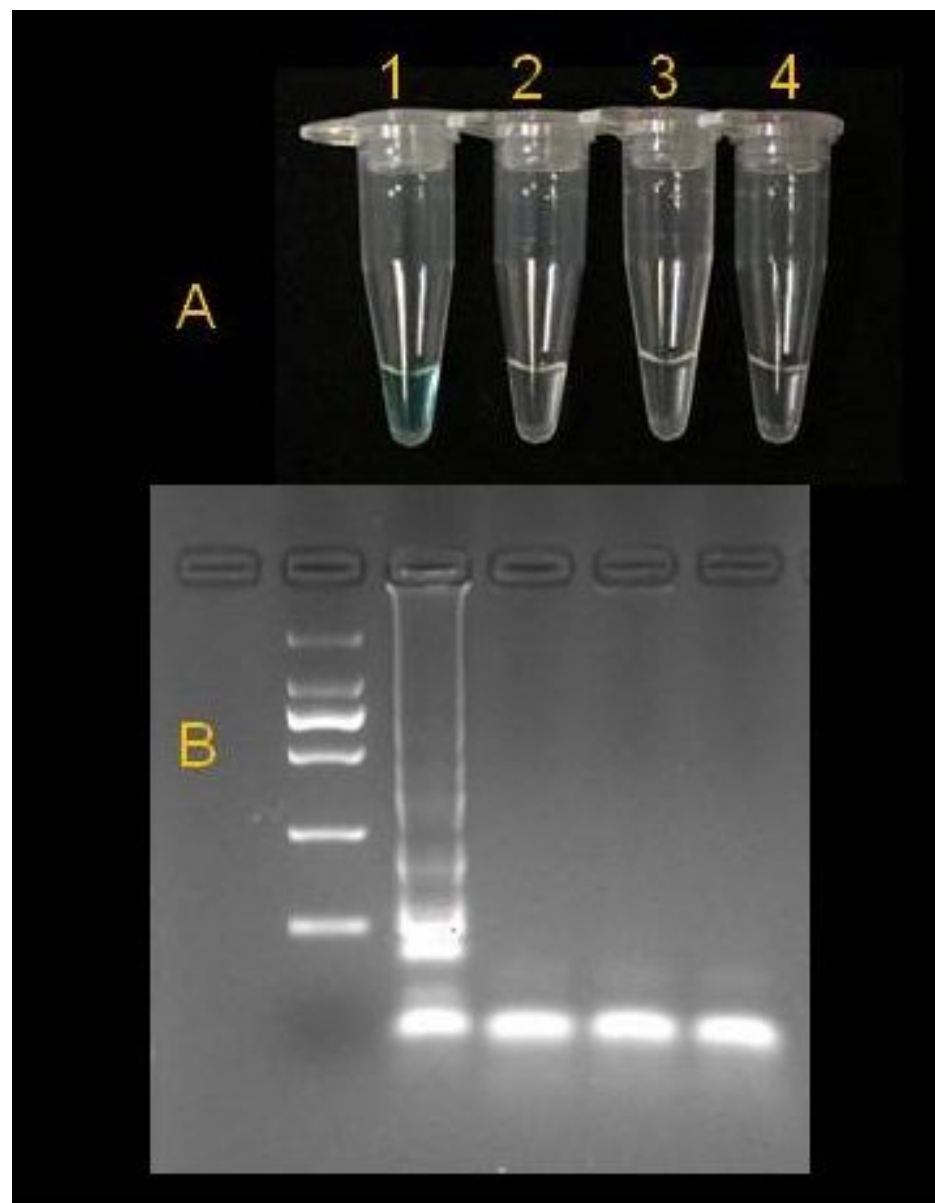

\section{Figure 2}

Confirmation and detection of products. (A) The color change seen in MCDA tubes: tube 1 is the positive amplification of PA, the green color was observed directly; tubes 2 and 3 are the negative amplifications of $\mathrm{S}$. aureus and K. pneumoniae respectively; tube 4 is the negative amplification of the control (no DNA);tubes 2, 3 and 4 remained colorless. (B) 2.5\% agarose gel electrophoresis applied to MCDA; lane 0:DL 100-bp DNA marker; lane 1: positive MCDA products of PA; lane 2 and 3: negative products of S. aureus and K. pneumoniae respectively; and lane 4, negative control (no DNA). 

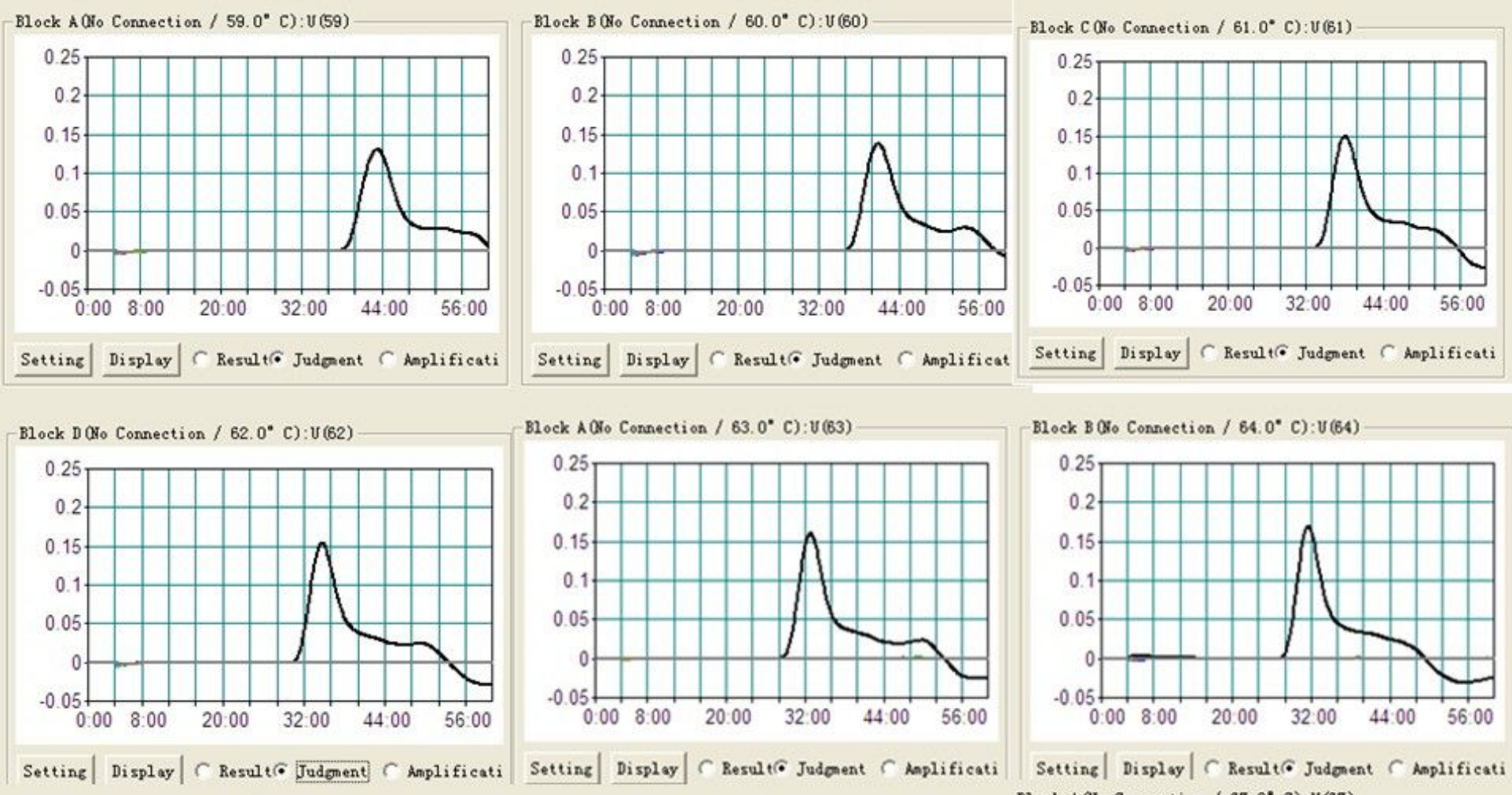

Block C Q o o Connection / $\left.65.0^{\circ} \mathrm{C}\right): \mathrm{U}(65)$

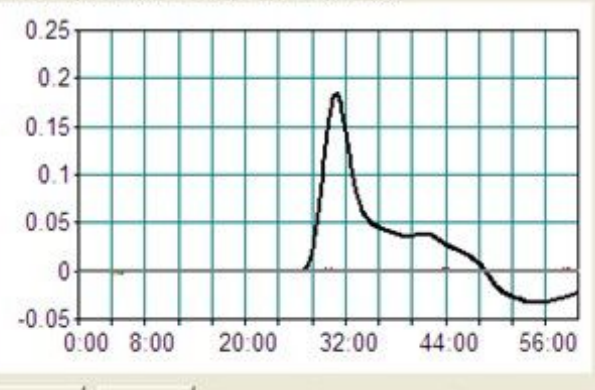

Block D (No Connection / $\left.66,0^{\circ} \mathrm{C}\right): U(66)$
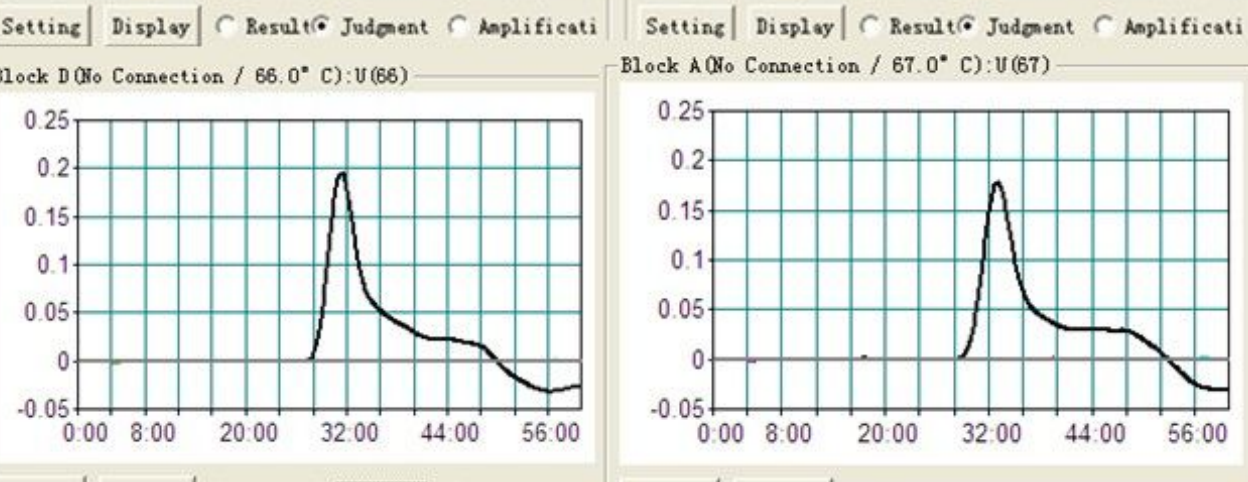
Block A ONo Connection / 67. $\left.0^{\circ} \mathrm{C}\right): \cup(67)$

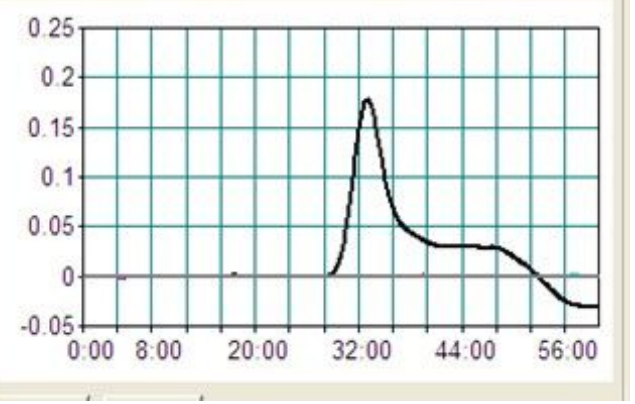

\section{Figure 3}

Optimal reaction temperature for the PA-MCDA primer assay. MCDA reactions when detecting the PA gene were monitored by real-time measurement of turbidity. A turbidity of $>0.1$ was considered positive. Nine kinetic graphs were obtained at various temperatures $(59-67 \circ \mathrm{C}$, at $1 \circ \mathrm{C}$ intervals) with PA DNA at a concentration of $1 \mathrm{ng}$ per tube. The graphs showed that $65^{\circ} \mathrm{C}$ was an optimal temperature for amplification. 


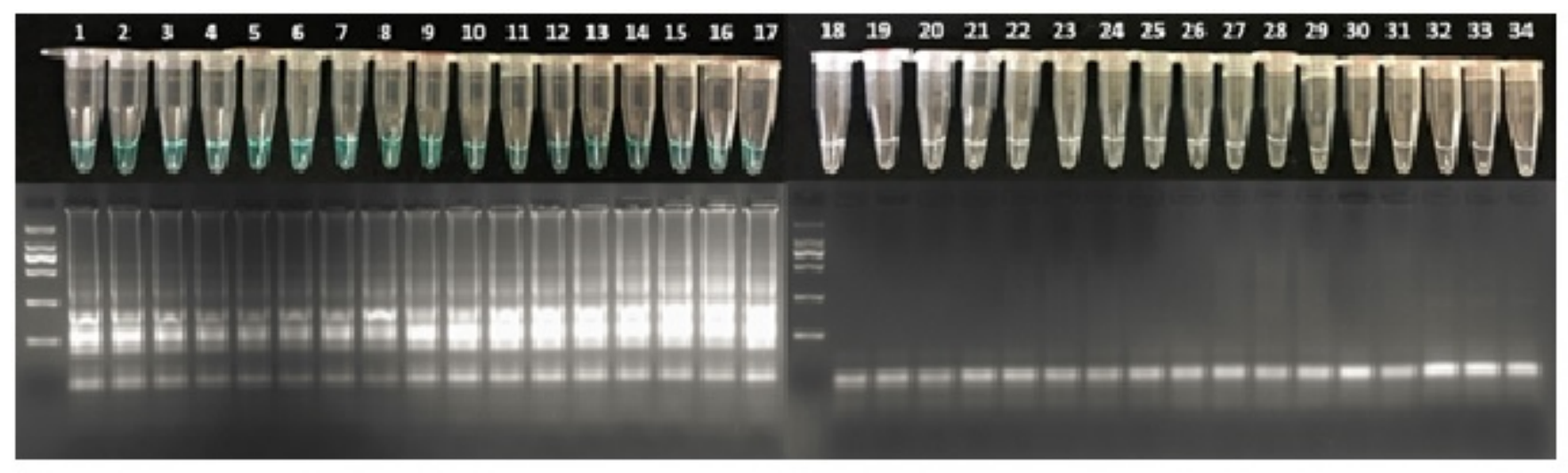

\section{Figure 4}

Specificity for PA detection by MCDA assays. Of all 77 pure genomic templates, only the genomic DNAs from the PA strains generated positive results. The color shift in the PA-MCDA tubes (tubes 1-17) was

directly observed as a green color. A grey color was seen in tubes 18-34, in which 18-21 were E.coli(ETEC, EAEC, EIEC and EHEC). Tubes 22-23 were S. aureus, of which, tubes 24-25 were A. baumannii, and tubes 26-34 were respectivelyS. epidermidis, S. capitis, Streptococcus pyogenes, S. agalactiae, E. faecalis,S. typhimurium, K. pneumoniae, E. cloacae, and S. maltophilia.A $2 \%$ agarose gel electrophoresis assay was applied to detect PA MCDA; lane 0, DL 100-bp DNA marker; lanes 1-17 were positive MCDA products that 
corresponded to PA tubes 1-17; and lanes 18-34 were negative and corresponded to tube 18-34 respectively.
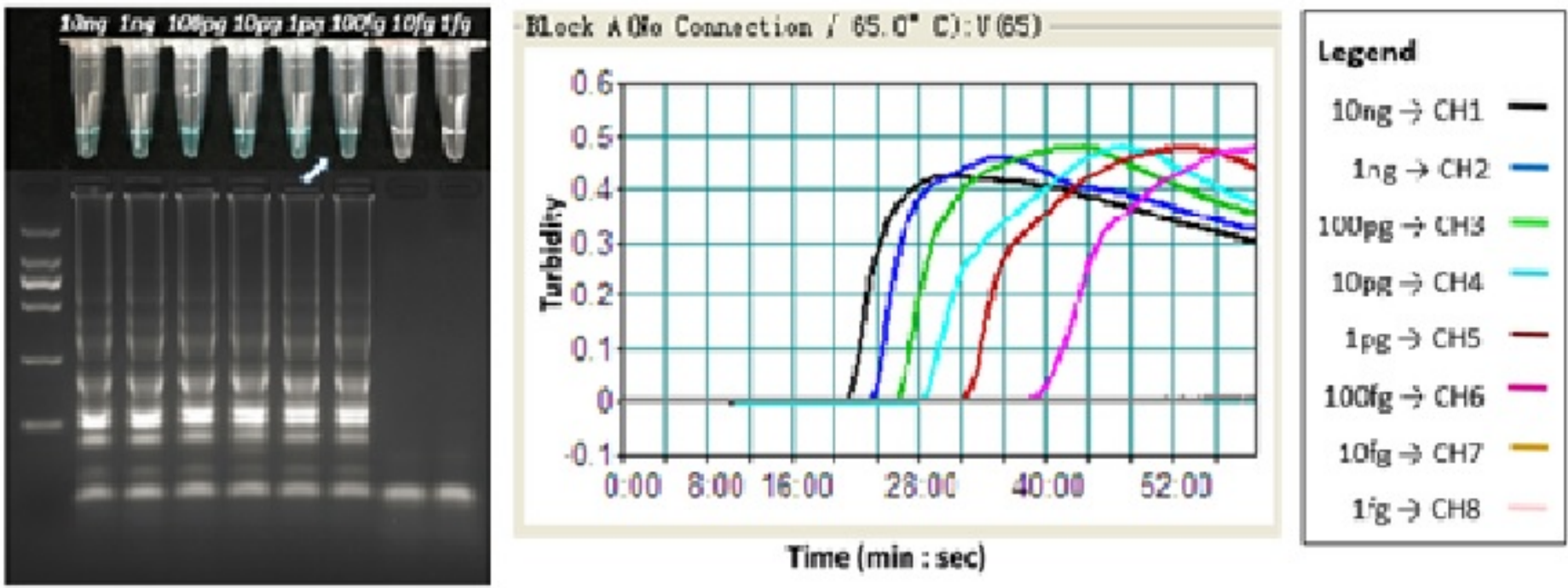

Time (min : sec)

\section{Figure 5}

Sensitivity of the MCDA assays using serially diluted PA genomic DNA. (A) PA genomic DNA was serially diluted to $10 \mathrm{ng}, 1 \mathrm{ng}, 100 \mathrm{pg}, 10 \mathrm{pg}, 1 \mathrm{pg}, 100 \mathrm{fg}, 10 \mathrm{fg}$ and $1 \mathrm{fg}$ per microliter. When the dilution was more than $100 \mathrm{fg} / \mathrm{uL}$, the green color by $M G$ and the laddering pattern by agarose gel electrophoresis were directly observed. The LoD of the PA MCDA assay was as low as $100 \mathrm{fg}$ per microliter (white arrow). (B) 
Real-time turbidity was applied to analyze the amplification products. Genomic DNA levels $>100 \mathrm{fg}$ per reaction produced positive reactions. 